\title{
EDUKASI PENGETAHUAN MENGENAI MIKROBA, OBAT, DAN MAKANAN UNTUK GENERASI SEHAT DAN CERDAS DI SMA NEGERI 9 SAMARINDA
}

\author{
Sister Sianturi ${ }^{1}$, Octaviana Maria Simbolon ${ }^{2}$, dan Nurillahi Febria Leswana ${ }^{3}$ \\ Program Studi S-1 Farmasi, STIKES Dirgahayu Samarinda \\ Jl. Pasundan No.21 Kelurahan Jawa, Kecamatan Samarinda Ulu, Kota Samarinda 75122 \\ e-mail: sianturisister16@gmail.com
}

\begin{abstract}
ABSTRAK
Pengetahuan dasar mengenai kesehatan sangat perlu diterapkan sejak dini, terlebih dengan semakin berkembangnya varian penyakit yang mengancam kesehatan manusia. Generasi yang cerdas dan sehat akan terwujud apabila segala aspek kesehatan diri seperti kebersihan diri, penggunaan obat secara benar, serta penggunaan gaya hidup sehat selalu diterapkan dalam aktivitas sehari-hari. Mitra pengabdian masyarakat yang dipilih adalah SMA Negeri 9 Samarinda. Sekolah ini merupakan salah satu sekolah yang terdapat di Kelurahan Lempake, Kecamatan Samarinda Utara. Banyaknya pedagang makanan disekitar wilayah sekolah, minimnya pengetahuan siswa mengenai obat-obatan, serta perilaku hidup bersih yang belum menjadi prioritas utama merupakan salah satu alasan yang mendasari terselenggaranya pengabdian masyarakat ini. Edukasi kepada siswa/i SMA N 9 Samarinda telah dilakukan secara daring dengan tema : "Pentingnya edukasi mengenai mikroba dan obat untuk generasi sehat dan cerdas". Kegiatan dilakukan selama 2 hari yaitu Sabtu dan Minggu tanggal 5-6 Juni 2021. Materi yang disampaikan dalam kegiatan ini adalah: konsep dasar mikrobiologi, patogenisitas dan flora normal bakteri dalam tubuh manusia, DAGUSIBU (Dapatkan, Gunakan, Simpan, dan Buang) Obat, penggolongan obat juga penggunaannya, serta pengetahuan mengenai Bahan Tambahan Pangan (BTP) dalam makanan juga bahaya dan efek penyalahgunaanya. Edukasi dilakukan dengan metode ceramah, diskusi, dan tanya jawab. Evaluasi dilakukan dengan menggunakan googleform berupa pre test dan post test untuk mengetahui pengetahuan peserta sebelum dan setelah diadakan edukasi. Penyampaian materi dapat meningkatkan pengetahuan siswa dengan indikator adanya peningkatan nilai post test secara signifikan baik pada hari pertama maupun pada hari kedua.
\end{abstract}

\section{Kata Kunci: Edukasi, DAGUSIBU, Bahan Tambahan Pangan, Mikrobiologi}

\begin{abstract}
Basic knowledge about health is very important to be known from early age. Especially nowadays there are so much variants of viruses found, which is very dangerous for human life. The smart and healthy generation will be formed if aspects of human health, such as personal hygiene, the right method of consuming medicine, and healthy lifestyle, always be applied in daily life. The partner of this activity was SMA Negeri 9 Samarinda. This school is located in Lempake, North Samarinda. Lots of school food merchants, lack of student education about medicine, also hygiene lifestyle that is not prioritized are some of the reason of this activity. The education activity for students of SMA Negeri 9 Samarinda was held online with "the importance of education about microbes and medicines for smart and healthy generation" theme. The activities were held for 2 days, from Saturday, June $5^{\text {th }}$ to Sunday June $6^{\text {th }}$ 2021. The delivered lessons from this activity were: the basic concept of microbiology, pathogenicity and normal
\end{abstract}


flora of bacteria in human body, DAGUSIBU (Get, Use, Save, dan Waste) of medicines, the classification of medicines and its function, and education about food additive and the effects if the medicine not consumed properly. The education activity was done with lectures, discussions, question and answer section. The evaluation was held in googleform with pre test and post test for knowing the student knowledge before and after the education activity is held. This activity succesfully increase student knowledge with the significant increase score from pre test to post test in both days as an indicator.

\section{Key Words: Education, DAGUSIBU, Food Additive, Microbiology}

\section{PENDAHULUAN}

Kelurahan Lempake adalah satu dai delapan kelurahan yang terdapat di Kecamatan Samarinda Utara. Luas wilayah ini sebesar $3.224 \mathrm{Ha}$ dengan jumlah populasi 16.883 orang. Jarak kelurahan ini dari pusat pemerintahan dan kecamatan sejauh $6 \mathrm{~km}$, jarak dari ibu kota kurang lebih $12 \mathrm{~km}$. Kelurahan Lempake memiliki banyak fasilitas pendidikan negeri antara lain SD Negeri 025 Samarinda Utara, SD Negeri 002 Samarinda Utara, SMP Negeri 13 Samarinda, dan juga SMA Negeri 9 (Website Resmi Kelurahan Lempake, 2021).

Mitra pengabdian masyarakat yang diusulkan adalah SMA Negeri 9 Samarinda. Sekolah ini merupakan salah satu sekolah yang terdapat di Kecamatan Samarinda Utara selain SMA Negeri 12 Samarinda. Sekolah ini berlokasi di Jalan Giri Rejo No. 154 RT. 24 Kelurahan Lempake, Kecamatan Samarinda Utara, Kalimantan Timur. Berdasarkan lokasi tersebut, maka sekolah ini termasuk sekolah yang berada di pinggiran desa dan jauh dari perkotaan Samarinda.

Visi dari SMA Negeri 9 Samarinda adalah unggul dalam prestasi yang berlandaskan pada imtaq dan iptek serta berwawasan lingkungan. Adapun misi dari sekolah ini adalah menanamkan akhlak mulia pada seluruh warga sekolah, meningkatkan prestasi di bidang akademik, meningkatkan bekal peserta didik dalam kegiatan ekstrakurikuler, menyiapkan kecakapan dan keterampilan komunikasi bahasa asing, meningkatkan pengetahuan peserta didik yang mampu untuk bersaing masuk perguruan tinggi, membudayakan sikap menghargai dan menghormati kepada semua dan menciptakan lingkungan sekolah dalam bidang HBS (Hijau, Bersih, Sehat) (Website Resmi SMA N 9 Samarinda, 2021).

Berdasarkan visi dan misi dari SMA Negeri 9 Samarinda, peningkatan pengetahuan peserta didik merupakan hal yang sangat penting. Pengetahuan adalah suatu proses mengingat dan mengenal kembali objek yang telah dipelajari melalui panca indra pada suatu bidang tertentu secara baik. Oleh karena itu, pentingnya pengetahuan dasar yang benar terkait makanan, obat-obatan dan mikrobiologi sehingga siswa memiliki sikap dan praktek yang benar terkait halhal tersebut di dalam kehidupan seharihari.

SMA Negeri 9 Samarinda merupakan sekolah yang berada di pinggiran desa dan jauh dari perkotaan Samarinda. Sebagai salah satu sekolah yang berada pada lokasi tersebut, maka tentunya terdapat penjual aneka jajanan atau makanan yang berada di sekitar lokasi sekolah. Ketika jam istirahat atau jam pulang sekolah, biasanya halaman sekolah sering disinggahi penjaja makanan seperti cilok, maklor, sempolan, telur gulung, bakso dan lain-lain. Hal ini dimungkinkan tidak semua jajanan anak sekolah ini terjamin 
keamanan ,kebersihan dan nilai gizinya. Menurut definisinya makanan sehat adalah makanan yang memenuhi standar kesehatan, yakni makanan yang bebas dari zat-zat berbahaya seperti pewarna sintetis ,pengawetan, serta pemanis buatan yang dilarang penggunaannya dalam makanan. Bahan-bahan tersebut biasa dikatakan sebagai bahan tambahan pangan (BTP). Umumnya produsen memberikan bahan tambahan ini untuk memperbaiki cita rasa dan kualitas makanan agar lebih menarik terutama bagi konsumen anak-anak. Namun demikian, seringkali bahan tambahan pangan yang digunakan oleh produsen tidak sesuai dengan kriteria yang dipersyaratkan seperti yang telah dituangkan dalam beberapa peraturan pemerintah. Syarat bahan tambahan yang dapat diaplikasikan pada produk makanan adalah harus aman, telah diuji dan dievaluasi keamanannya, tidak membahayakan konsumen pada kadar yang diijinkan, memenuhi syarat mutu dan kemurnian dan penggunaannya dibawah kadar yang diijinkan (Sriatun et al, 2019).

Lokasi sekolah yang berada cukup jauh dari ibukota tentunya mengakibatkan keterbatasan dalam menjangkau fasilitas kesehatan termasuk apotek. Bentuk peresepan dan juga penggunaan obat yang tidak tepat, termasuk penyimpanan obat di rumah oleh masyarakat ketika melakukan swamedikasi (pengobatan sendiri), dan memperoleh antibiotik tanpa adanya resep dokter, merupakan perilaku masyarakat yang keliru dan membuat pengobatan menjadi tidak rasional. Dampak dari perilaku tersebut dapat membahayakan masyarakat sendiri, karena dapat terjadi reaksi obat yang tidak dikehendaki/ efek samping, hingga meningkatnya resistensi terhadap suatu antibiotik. DAGUSIBU (DApatkan, GUnakan, SImpan, BUang) adalah Program Gerakan Keluarga Sadar Obat yang diprakarsai oleh Ikatan Apoteker
Indonesia dalam mencapai pemahaman dan kesadaran masyarakat terhadap penggunaan obat dengan benar. DAGUSIBU merupakan salah satu upaya peningkatan kesehatan bagi masyarakat yang diselenggarakan melalui kegiatan pelayanan kesehatan oleh tenaga kefarmasian (Yusransyah et al, 2021).

Lokasi SMAN 9 Samarinda yang berada di sekitar pemukiman desa juga mempengaruhi perilaku hidup bersih dalam kesehatan remaja tersebut. Perilaku hidup bersih belum menjadi prioritas utama. Siswa cenderung banyak bermain di luar rumah dan tidak mendapat pengawasan dari orang tua. Hal ini secara tidak langsung akan berdampak pada pertumbuhan dan perkembangan remaja. Pengetahuan mengenai jenis-jenis bakteri yang dapat menyebabkan penyakit penting bagi siswa untuk meningkatkan kesadaran siswa terhadap pola hidup bersih dan sehat bagi keluarga sehingga kesehatan dan pertumbuhan remaja dapat optimal. Selain itu, pengetahuan tentang flora normal bakteri dalam tubuh akan meningkatkan kesadaran siswa tentang sistem pertahanan tubuh di dalam menunjang kesehatan.

Berdasarkan latar belakang diatas, maka kegiatan ini dilakukan untuk mengedukasi siswa/siswi SMA Negeri 9 Samarinda mengenai pentingnya pengetahuan tentang mikroba, obat, dan makanan untuk generasi sehat dan cerdas.

\section{METODE}

Pelaksanaan kegiatan pengabdian kepada masyarakat dilakukan dengan metode penyuluhan atau edukasi secara online. Proses sosialisasi kegiatan dilakukan dengan meyebarkan flyer kegiatan melalui berbagai media sosial dan pemberitahuan melalui guru/wali kelas. Tema kegiatan ini adalah "Pentingnya Pengetahuan Mengenai Mikroba, Obat, dan Makanan Untuk 
Generasi Sehat dan Cerdas" yang disampaikan oleh dosen Program Studi S-1 Farmasi STIKES Dirgahayu Samarinda. Kegiatan dilaksanakan selama 2 hari, yaitu Sabtu dan Minggu tanggal 5-7 Juni 2021 secara daring. Peserta kegiatan adalah siswa/I SMA Negeri 9 Samarinda.

Materi edukasi yang disampaikan pada kegiatan ini terdiri atas 6 materi yang disampaikan dalam 2 hari. Pada hari pertama tanggal 5 Juni 2021 materi yang disampaikan adalah Konsep dasar mikrobiologi, peranan Mikroorganisme dalam produk makanan dan obat; dan Memahami DAGUSIBU (Dapatkan, Gunakan, Simpan, dan Buang) Obat, dan bahan tambahan pangan pada makanan. Pada hari kedua tanggal 06 Juni 2021 materi yang disampaikan adalah Patogenisitas dan Flora Normal Bakteri dalam Tubuh Manusia, Pengenalan Penggolongan Obat dan bahaya serta efek penyalahgunaan Bahan Tambahan Pangan (BTP).

Tahapan pelaksanaan kegiatan ini adalah sebagai berikut: yang pertama, rapat strategi pelaksanaan kegiatan, Rapat ini dilakukan oleh tim pelaksana kegiatan terkait persiapan, sasaran, dan strategi pelaksanaan kegiatan. Di dalam rapat ini juga dilakukan diskusi pembagian tugas untuk kelancaran pada saat hari pelaksanaan. Hasil dari rapat ini adalah disepakati sasaran kegiatan dan strategi pelaksanaan; kedua, survei lokasi dan diskusi kesepakatan dengan pihak sekolah, Tim mendatangi sekolah yang akan menjadi sasaran sekolah dan melakukan diskusi dan kesepakatan terkait pelaksanaan kegiatan. Tim membawa Surat Ijin Kegiatan dari Instansi sebagai bentuk legalitas kegiatan. Hasil dari tahap ini adalah tercapai kesepakatan pelaksanaan kegiatan secara daring. Dalam hal ini partisipasi guru atau pihak sekolah adalah turut menyampaikan informasi terkait kegiatan dan jadwal kegiatan kepada siswa/i. Selain itu, guru atau pihak sekolah turut dalam pelaksaaan kegiatan pada saat hari $H$. ketiga, sosialisasi kegiatan, Sosialisasi terkait pelaksanaan kegiatan dilakukan dengan menyebarkan flyer melalui media sosial. Informasi ini juga disampaikan oleh pihak sekolah kepada siswa untuk berpartisipasi dalam pelaksanana kegiatan. Flyer juga disebarkan melalui instagram resmi sekolah. Ke-empat, pelaksanaan kegiatan edukasi, kegiatan dilaksanakan pada hari sabtu, 5 Juni 2021 dan minggu, 6 Juni 2021 mulai pukul 08.30 sampai jam 12.00 dengan rangkaian kegiatan termasuk pembukaan, pelaksaan pre test, penyampaian materi 1 dan 2, sesi diskusi, pelaksanaan post test serta sesi foto dan penutup.

Kelima, pre test dan post test, Kegiatan ini dilakukan sebelum dan sesudah penyampaian materi. Pre test adalah kegiatan menguji tingkat $\mathrm{e}$ responden mengenai materi yang akan disampaikan. Jumlah soal adalah sebanyak 10 soal yang mencakup semua materi yang disampaikan. Pertanyaan disampaikan melalui google form dan link nya disampaikan ke siswa. Waktu pelaksanaan soal masing-masing pre test dan post test adalah 15 menit. Post test adalah kegiatan menguji tingkat pengetahuan responden setelah mendengarkan pemaparan materi. Dengan membandingkan hasil post test dan pre test dapat diperoleh evaluasi terhadap kegiatan apakah dapat memberi hasil yang baik dengan indikator adanya peningkatan nilai rata-rata post test siswa apabila dibandingkan dengan nilai ratarata pre test. Ke-enam, sesi diskusi dan penutup, Sesi diskusi dilakukan setelah materi disampaikan. Peserta dipersilahkan menyampaikan pertanyaan atau pendapat melalui kolom chat pada aplikasi atau menyampaikan secara langsung melalui forum daring. Setiap peserta yang aktif dalam kegiatan diberikan apresiasi oleh tim melalui pemberian hadiah berupa saldo Gopay. Acara ditutup dengan penyampaikan 
kesan dan pesan selama kegiatan dari peserta lalu penyampaian terima kasih dari tim pelaksana kegiatan. Sesi foto bersama dilakukan untuk dokumentasi dan kelengkapan laporan kegiatan. Ketujuh, evaluasi kegiatan, evaluasi ini dilakukan antara pihak pelaksanan kegiatan dengan pihak sekolah terkait penyampaian laporan kegiatan, hasil kegiatan, dan keberlanjutan kerjasama antara tim dengan sekolah. Kerjasama antara tim dengan mitra akan berlanjut dengan pelaksanaan kegiatan yang terkait dengan edukasi dari tim pelaksana dengan mitra dengan topik yang berbeda. Evaluasi keberhasilan atau pencapaian tujuan dalam kegiatan juga ditinjau dengan membandingkan rekapitulasi nilai pre test dan post test siswa.

\section{HASIL dan PEMBAHASAN}

Kegiatan pengabdian kepada masyarakat ini mengusung tema: Edukasi Pengetahuan Mengenai Mikroba, Obat, dan Makanan untuk Generasi Sehat dan Cerdas di SMA Negeri 9 Samarinda. Kegiatan edukasi ini diadakan dengan tujuan agar memberikan pengetahuan dasar yang benar terkait makanan, obat-obatan dan mikrobiologi sehingga siswa memiliki sikap dan praktek yang benar terkait halhal tersebut di dalam kehidupan seharihari.

Kegiatan pengabdian kepada masyarakat ini dilakukan pada tanggal 56 Juni 2021 dengan tema "Pentingnya Pengetahuan Mengenai Mikroba, Obat, dan Makanan Untuk Generasi Sehat dan Cerdas" di SMA Negeri 9 Samarinda dan diikuti oleh 116 siswa secara online/daring berjalan dengan lancer.

Kegiatan diawali dengan sosialisasi kepada siswa/I untuk dapat mengikuti edukasi yang dilakukan dengan penyebaran flyer kegiaatan melalui media sosial guru maupun siswa. Kemudian dilanjutkan dengan
Pelaksanaan kegiatan edukasi yang dilaksanakan sesuai dengan susunan acara dimana pembukaan, dilakukan di awal kegiatan yang disampaikan oleh pihak sekolah yang diwakili oleh guru/wali kelas dan tim pelaksana sebagai temu awal pelaksanaan kegiatan. Kegiatan dilanjutkan dengan pelaksanaan pretest, yaitu yang bertujuan untuk mengetahui tingkat pengetahun siswa terkait materi yang disampaikan. Kegiatan ini dilakukan selama 20 menit melalui google form yang sudah dipersiapkan oleh tim.

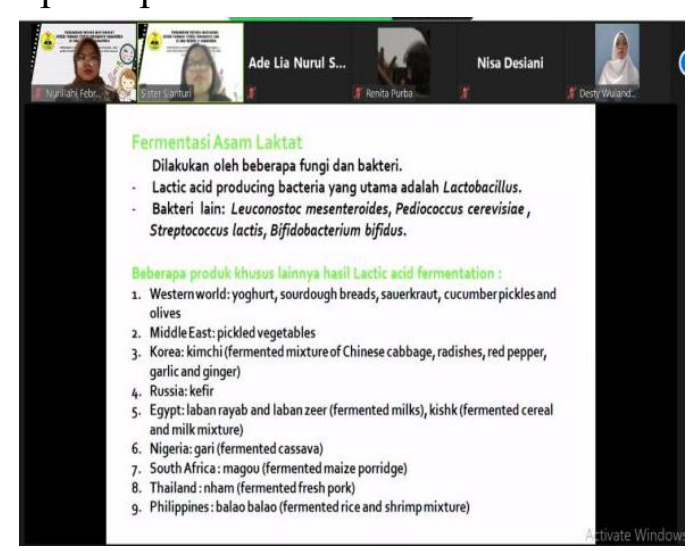

Gambar 1. Penyampaian materi Konsep dasar mikrobiologi, serta patogenisitas dan flora normal bakteri dalam tubuh manusia

Penyampaian materi dilakukan oleh tim sesuai dengan bidang keahlian masing-masing yaitu Sister Sianturi, S.Si., M.Si, menyampaikan materi: Konsep dasar mikrobiologi serta patogenisitas dan flora normal bakteri dalam tubuh manusia (Gambar 1). Apt. Octaviana Maria Simbolon, M.Farm.Klin, menyampaikan materi: DAGUSIBU (Dapatkan, Gunakan, Simpan, dan Buang) Obat, Penggolongan Obat juga Penggunaanya (Gambar 2) serta Nurillahi Febria Leswana, S.Si., M.Sc menyampaikan materi mengenai bahan tambahan pangan serta bahaya dan efek penyalahgunaannya (Gambar 3).

Materi diberikan secara berurutan sesuai dengan susunan acara yang telah dibuat. Materi untuk masing-masing 
pemateri dibagi menjadi 2 sesi dengan hari yang berbeda.

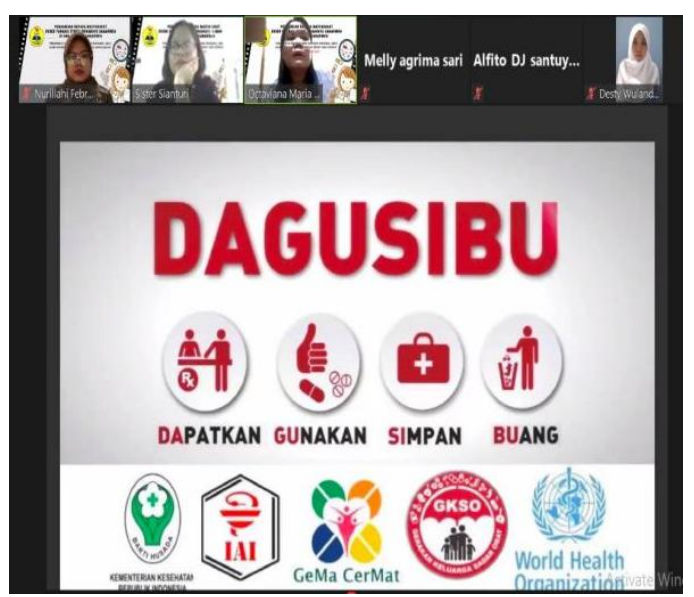

Gambar 2. Penyampaian materi DAGUSIBU (Dapatkan, Gunakan, Simpan, dan Buang) Obat, penggolongan obat juga penggunaannya.

Meskipun berlangsung secara daring/online dengan menggunakan platform zoom meeting, namun dalam penyampaian materi juga tetap dilakukan dialog interaktif tanya jawab sehingga peserta dapat memberikan respon pada materi yang diberikan.

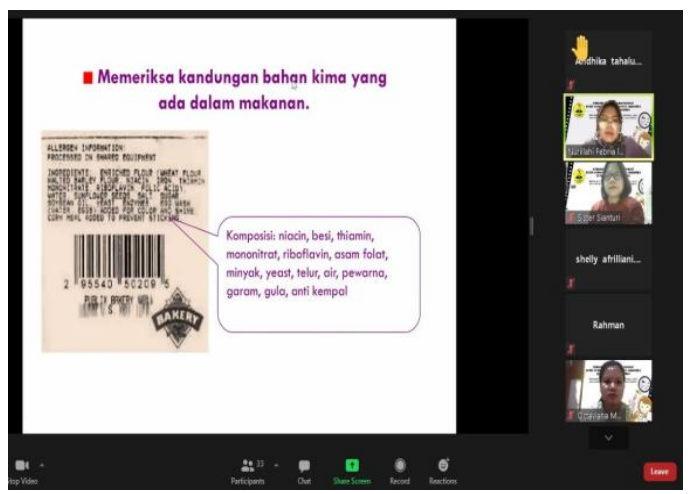

Gambar 3. Penyampaian materi bahan tambahan pangan dalam makanan serta bahaya dan efek penyalahgunaanya.

Salah satu parameter keberhasilan kegiatan pengabdian masyarakat ini adalah dengan mengamati data evaluasi berupa pretest dan post test yang diadakan oleh tim. Pengujian tingkat pengetahuan responden setelah mendengarkan pemaparan materi dilakukan dengan pelaksanaan post test.

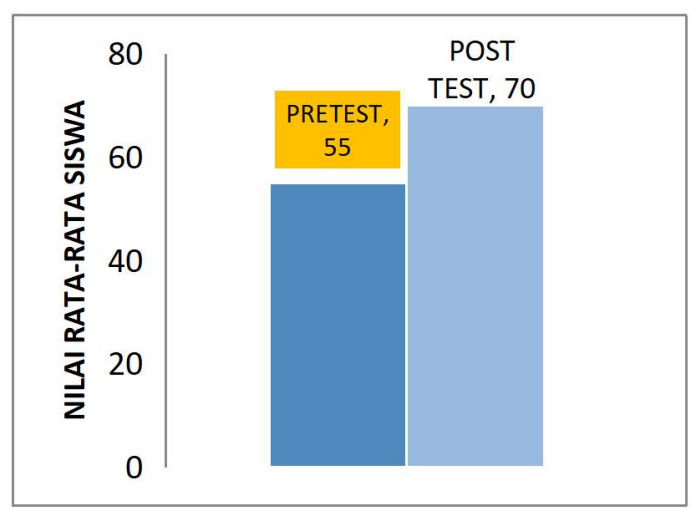

Gambar 4. Perbandingan rata-rata nilai pretest dan postest siswa pada materi hari pertama

Pelaksanaan Pre test dan post test dilakukan selama 2 hari yairu sebelum dan sesudah proses penyuluhan berlangsung. Dengan membandingkan hasil post test dan pre test dapat diperoleh evaluasi terhadap kegiatan apakah dapat memberi hasil yang baik dengan indikator adanya peningkatan nilai rata-rata post test siswa apabila dibandingkan dengan nilai rata-rata pre test

Pada penyampaian edukasi hari pertama rata-rata nilai pretest adalah 55 dan nilai post test adalah 70 (Gambar 4). Lalu pada penyampaian edukasi hari kedua nilai rata-rata pretest adalah 60 dan nilai post test adalah 81 (Gambar 5). Berdasarkan hasil tersebut disimpulkan bahwa terdapat peningkatan pengetahuan siswa pada kegiatan edukasi baik pada hari pertama maupun hari kedua. Hal ini menunjukkan bahwa penyampaian edukasi dapat dipahami oleh siswa dengan indikator meningkatnya nilai siswa pada post test.

Edukasi mengenai mikroba dan obat ini penting bagi siswa untuk meningkatkan pengetahuan siswa dan memahami swamedikasi yang benar di lingkungan masyarakat. Selain itu, siswa perlu diberi pemahaman tentang mikroba dan peranannya di tengah masa pandemi. Siswa tidak terfokus hanya dengan bahaya mikroba tetapi juga memahami 
bagaimana peranan mikroba dalam pembuatan makanan dan obat-obatan.

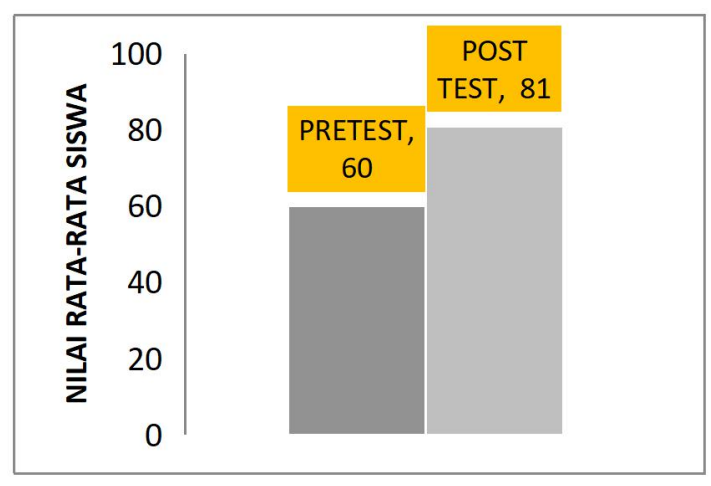

Gambar 5. Perbandingan rata-rata nilai pretest dan postest siswa pada materi hari kedua

Kegiatan edukasi ditutup dengan adanya pemberian hadiah kepada siswa yang aktif diskusi dan bertanya selama penyampaian materi edukasi. Hadiah berupa saldo Gopay dengan nilai masing-masing Rp. 50.000,00 untuk 10 orang siswa. Hal ini dilakukan untuk memotivasi siswa untuk antusias dalam forum diskusi sehingga suasana penyampaian edukasi tidak monoton. Selain kepada siswa, tim juga memberikan souvenir kepada guru/wali kelas berupa handsanitizer dan handsoap untuk dapat dipergunakan di sekolah

\section{KESIMPULAN DAN SARAN}

Edukasi kepada siswa/i SMA N 9 Samarinda telah dilakukan secara daring dengan tema : "Pentingnya edukasi mengenai mikroba dan obat untuk generasi sehat dan cerdas". Kegiatan dilakukan selama 2 hari yaitu Sabtu dan Minggu tanggal 5-6 Juni 2021. Penyampaian materi dapat meningkatkan pengetahuan siswa dengan indikator adanya peningkatan nilai post test secara signifikan baik pada hari pertama maupun pada hari kedua. Saran untuk kegiatan ini adalah perlu dilakukan kegiatan edukasi dengan materi lain untuk meningkatkan pengetahuan siswa. Dan perlu dilakukan diskusi antara tim dan mitra tentang keberlanjutan kerjasama kedua belah pihak.

\section{DAFTAR PUSTAKA}

Sriatun, Azmiyawati, C., Darmawan, A., Arnelli, Astuti, Y . (2019). Laporan Kegiatan Pengabdian Masyarakat tentang Penyuluhan Makanan Sehat dan Bahan Tambahan Pangan bagi Anak Sekolah'. Departemen Kimia Fakultas Sains dan Matermatika Universitas Diponegoro: Semarang. Yusransyah, Stiani, S. N., Zahroh, S. L. (2021). Pengabdian Masyarakat tentang DAGUSIBU (Dapatkan, Gunakan, Simpan, dan Buang) ObatdenganBenar di SMK IKPI Labuan Pandeglag. JurnalAsta Vol. 1 No. 1, 22-31.

Website Resmi Kelurahan Lempake. Profil Kelurahan Lempake. Diakses pada 27 Juli 2021, dari http://kellempake.samarindakota.go.id/

Website Resmi SMAN 9 Samarinda. Profil SMAN 9 Samarinda. Diakses pada 27 Juli 2021, dari http://sma9smd.sch.id/

Website Universitas Katolik Indonesia Atmajaya. 2019. Penyuluhan Sanitasi dan Komunitas Bakteri. Diakses dari https://m.atmajaya.ac.id/web/Kont enFakultas.aspx?gid=beritafakultas\&ou=teknobiologi\&cid $=20$ 20-01-pengabdian 